\title{
Hubungan Kadar Vitamin D dengan Anak Atopi dan Obesitas
}

\author{
Elza Noviani, Dwi Prasetyo, Budi Setiabudiawan \\ Departemen Ilmu Kesehatan Anak Fakultas Kedokteran Universitas Padjadjaran/Rumah Sakit Dr. Hasan \\ Sadikin, Bandung
}

\begin{abstract}
Latar belakang. Angka kejadian penyakit atopik dan obesitas meningkat bersamaan. Hubungan kadar vitamin $\mathrm{D}$ dengan atopi masih kontroversial.

Tujuan. Menilai hubungan kadar vitamin D dengan anak atopi dan obesitas.

Metode. Penelitian desain potong silang, sejak bulan Agustus sampai Desember 2013, terhadap 62 anak obesitas dan gizi normal murid sekolah dasar Kota Bandung. Kadar vitamin D-25 OH serum diukur dengan metode chemiluminescent immunoassay, dilakukan uji tusuk kulit dan kuosioner The International Study Of Asthma And Allergies In Childhood. Analisis data dengan uji chi Kuadrat dan two-way Anova.

Hasil. Tidak terdapat perbedaan rerata kadar vitamin $\mathrm{D}$ antara kelompok anak obesitas dan status gizi normal $(\mathrm{p}=0,994)$. Tidak terdapat perbedaan rerata kadar vitamin $\mathrm{D}$ antara kelompok atopi dan non-atopi $(\mathrm{p}=0,58)$. Tidak terdapat interaksi antara kelompok atopi dan status gizi terhadap kadar vitamin $D(p=0,24)$. Kesimpulan. Tidak terdapat hubungan antara kadar vitamin D dengan anak atopi dan obesitas. Sari Pediatri 2015;16(5):342-6.
\end{abstract}

Kata kunci: vitamin D, atopi, obesitas, gizi normal

$\mathrm{P}$ revalensi obesitas telah meningkat drastis dalam 2 dekade terakhir. Di Amerika Serikat, berdasarkan data dari National Health and Nutrition Examination Survey (NHANES) dibandingkan dengan tahun 1980, obesitas mengalami peningkatan hingga tiga kali lipat, terutama pada anak berusia 6-11 tahun. ${ }^{1,2} \mathrm{Di}$ Indonesia, pada tahun 2011, prevalensi obesitas anak

\section{Alamat korespondensi:}

Prof. Dr. dr. Budi Setiabudiawan Sp.A(K), M.Kes. Departemen Ilmu Kesehatan Anak Fakultas Kedokteran Universitas Padjadjaran/Rumah Sakit Dr. Hasan Sadikin. Jl. Pasteur No. 38 Bandung 40163, Indonesia, No telepon: 022-2035957. E-mail: setiabudiawan@yahoo.com usia 5-15 tahun $8,3 \% .^{3}$

Di Amerika Serikat, prevalensi insufisiensi vitamin D meningkat hingga dua kali lipat dibandingkan dengan 10 tahun yang lalu. ${ }^{4}$ Defisiensi vitamin D telah diteliti sebelumnya dalam populasi anak dengan obesitas. ${ }^{1}{ }^{2}$ Keterkaitan vitamin D dengan obesitas menjadi daya tarik para peneliti yang memperlihatkan tidak hanya suatu kondisi penimbunan jaringan adiposa, tetapi juga peningkatan kadar leptin. Leptin melalui fibroblast growth factor-23 (FGF-23), yaitu faktor fosfaturik yang berperan dalam metabolisme vitamin D di ginjal dapat menekan sintesis D $1,25(\mathrm{OH})_{2}$, bentuk aktif vitamin $\mathrm{D}$ yang dibentuk di ginjal. Selain itu, leptin secara langsung dapat menekan ikatan 
vitamin $\mathrm{D} 25(\mathrm{OH})$ yang berada disirkulasi dengan 1 -hydroxylase (CYP27B1) dan 1,25-hydroxyvitamin D-24-hydroxylase (CYP24) pada ginjal dan jaringan adiposa. Terdapat pula teori yang menyatakan bahwa dengan peningkatan jaringan adiposa maka vitamin D yang larut lemak akan tersimpan dalam jaringan adiposa tersebut sehingga menyebabkan defisiensi vitamin D., 6

Defisiensi vitamin D dinyatakan dapat menstimulasi sel B sehingga dapat meningkatkan produksi IgE spesifik sebagai penanda atopi. Defisiensi vitamin D berkaitan dengan penyakit atopik, meskipun hingga saat ini penelitian yang berskala besar dan randomisasi masih terbatas. ${ }^{7}$ Penelitian yang menghubungkan vitamin D dengan penyakit atopik hingga saat ini hasilnya masih bervariasi dan kontradiktif., ${ }^{2,7}$ Penelitian analitik observasional dengan desain case control yang dilakukan di Rumah Sakit Massachusetts, Boston, meneliti subjek berusia $\geq 10$ tahun menunjukkan adanya peningkatan kejadian dermatitis atopik pada pasien obesitas dengan defisiensi vitamin $\mathrm{D}$ dibandingkan dengan pasien yang memiliki kadar vitamin D yang normal, tetapi tidak terhadap hubungan dengan kejadian asma dan rhinitis alergika. ${ }^{10}$ Tujuan penelitian adalah menentukan adanya hubungan kadar vitamin D dengan atopi dan obesitas.

\section{Metode}

Penelitian analitik komparatif dengan rancangan potong silang yang dilakukan pada Agustus 2013 Desember 2013. Subjek penelitian adalah anak berusia 6-11 tahun dari beberapa sekolah dasar di Kotamadya Bandung. Kriteria inklusi adalah anak sehat berusia 6-11 tahun, memenuhi kriteria obesitas dan gizi normal menurut WHO 2007, dan bersedia mengikuti penelitian. Kriteria eksklusi adalah anak yang sedang dalam pengobatan (obat yang mengganggu respon uji tusuk kulit dan belum menghentikan penggunaan obat minimal 1 minggu seperti antihistamin, antidepresi, antipsikotik, antiemetik, sedatif, relaxant, dan kortikosteroid topical), kelainan dermatologi yang luas, dermatografisme berat, pengguna suplemen vitamin D >400 IU/hari, dan secara klinis tidak menderita penyakit hepar, renal, malabsorpsi, kelainan tulang/ kelainan metabolisme kalsium yang dapat menyebabkan defisiensi vitamin D. Penelitian dilakukan pada 62 anak obesitas dengan gizi normal. Penelitian telah mendapat persetujuan Komite Etik Penelitian Kesehatan Fakultas Kedokteran Universitas Padjadjaran/RSUP Dr. Hasan Sadikin Bandung. Persetujuan ikut serta dalam penelitian didapatkan dari orangtua/wali penderita. Data penelitian diperoleh dari anamnesis, pemeriksaan fisik, pengisian kuosioner the international study of asthma and allergies in childhood (ISAAC) oleh orangtua. Kemudian dilakukan juga pemeriksaan kadar vitamin $\mathrm{D} 25-\mathrm{OH}$ dengan metode chemiluminescent immunoassay dan uji tusuk kulit terhadap 12 alergen, yaitu Blomia tropicalis, Dermatophagoides farinae, Dermatophagoides pteronyssinus, Alternaria alternata, Aspergillus mix, cockroach mix, white egg, yolc egg, chocolate, crab, shrimp, soya. Analisis data dilakukan dengan menggunakan uji chi Kuadrat dan Two Way Anova dengan program SPSS for windows versi 15.0, nilai $\mathrm{p}<0,05$.

\section{Hasil}

Selama 4 bulan penelitian didapatkan 62 subjek dengan status gizi obesitas dan gizi normal. Pada kelompok anak obesitas dan gizi normal, usia dan jenis kelamin menunjukkan karakteristik yang homogen. Pendidikan ibu lebih banyak di tingkat menengah atas, baik pada kelompok obesitas maupun gizi normal. Pada kelompok obesitas, pendidikan ayah lebih banyak di tingkat tinggi, sedangkan kelompok gizi normal lebih banyak di tingkat menengah atas. Pendapatan orang tua sama tinggi baik pada kelompok obesitas maupun gizi normal (Tabel 1).

Suplementasi vitamin D dan asupan susu memperlihatkan tidak adanya perbedaan bermakna antara kelompok obesitas dan status gizi normal, dengan nilai $p>0,05$ (Tabel 2). Rerata kadar vitamin D tidak memiliki perbedaan bermakna antara kelompok anak obesitas dan gizi normal, rerata kadar vitamin $\mathrm{D}$ tidak memiliki perbedaan bermakna antara kelompok atopi dan obesitas. Begitu pula tidak terdapat interaksi antara kelompok atopi, non atopi, dan status gizi terhadap kadar vitamin $\mathrm{D}$.

\section{Pembahasan}

Hasil penelitian menunjukkan tidak terdapat perbedaan rerata kadar vitamin D antara kelompok anak obesitas dan gizi normal, juga antara kelompok atopi 
Tabel 1. Karakteristik umum subjek penelitian

\begin{tabular}{lcc}
\hline & \multicolumn{2}{c}{ Status gizi } \\
\cline { 2 - 3 } Karakteristik & $\begin{array}{c}\text { Obesitas } \\
(\mathrm{n}=31)\end{array}$ & $\begin{array}{c}\text { Gizi normal } \\
(\mathrm{n}=31)\end{array}$ \\
\hline Usia (tahun) & $9(1,7)$ & $9(1,7)$ \\
Rerata (SD) & $6,0-11,0$ & $6,0-11,0$ \\
Rentang & & \\
Jenis kelamin & 19 & 19 \\
Laki-laki & 12 & 12 \\
Perempuan & & 1 \\
Pendidikan ibu & 2 & 5 \\
Dasar & 4 & 15 \\
Menengah pertama & 13 & 0 \\
Menengah atas & 12 & 5 \\
Tinggi & & 17 \\
Pendidikan ayah & 5 & 9 \\
Dasar & 2 & 9 \\
Menengah pertama & 9 & 10 \\
Menengah atas & 15 & 12 \\
Tinggi & & \\
Pendapatan keluarga (rupiah/per bulan) & 6 & \\
$\quad$ Rendah: $<850.000$ & 10 & \\
Sedang: $850.000-1.600 .000$ & 15 & \\
Tinggi: $>1.600 .000$ & & \\
\hline
\end{tabular}

Tabel 2. Asupan vitamin D

\begin{tabular}{|c|c|c|c|}
\hline \multirow[b]{2}{*}{ Faktor Lingkungan } & \multicolumn{2}{|c|}{ Status gizi } & \multirow[b]{2}{*}{$\mathrm{p}$} \\
\hline & $\begin{array}{l}\text { Obesitas } \\
\qquad(\mathrm{n}=31)\end{array}$ & $\begin{array}{l}\text { Gizi normal } \\
\quad(n=31)\end{array}$ & \\
\hline \multicolumn{4}{|l|}{ Suplementasi vitamin D } \\
\hline Setiap hari & 0 & 2 & 0,373 \\
\hline Kurang dari tiap hari, $>1 \mathrm{x} /$ minggu & 4 & 6 & \\
\hline$\leq 1 \mathrm{minggu} / \mathrm{x}$ & 4 & 5 & \\
\hline Tidak pernah & 23 & 18 & \\
\hline \multicolumn{4}{|c|}{ Asupan susu (termasuk sereal, coklat) dalam 30 hari terakhir } \\
\hline Setiap hari & 10 & 12 & 0,596 \\
\hline Kurang dari tiap hari, $>1 \mathrm{x} / \mathrm{minggu}$ & 11 & 11 & \\
\hline$\leq 1 \mathrm{minggu} / \mathrm{x}$ & 8 & 6 & \\
\hline Tidak pernah & 2 & 2 & \\
\hline
\end{tabular}

Keterangan: Nilai p berdasarkan Uji Chi Kuadrat

Tabel 3. Hubungan kadar vitamin D dengan anak atopi dan obesitas

\begin{tabular}{|c|c|c|c|c|}
\hline \multirow{4}{*}{$\begin{array}{l}\text { Kadar Vitamin } \\
\text { D } 25-\mathrm{OH} \\
(\mathrm{ng} / \mathrm{mL})\end{array}$} & & \multicolumn{2}{|c|}{ Status gizi } & \multirow{2}{*}{$\mathrm{p}$} \\
\hline & & $\begin{array}{l}\text { Obesitas } \\
(\mathrm{n}=31)\end{array}$ & $\begin{array}{r}\text { Gizi normal } \\
(\mathrm{n}=31)\end{array}$ & \\
\hline & Atopi & 18,25 & 20,77 & $\left.0,994^{*}\right)$ \\
\hline & Non atopi & 19,59 & 17,03 & $\begin{array}{c}\left.0,58^{* *}\right) \\
\left.0,24^{* * *}\right)\end{array}$ \\
\hline
\end{tabular}

Keterangan: Nilai $\mathrm{p}=$ two-way Anova ${ }^{*}$ ) nilai $\mathrm{p}$ perbedaan rata-rata kadar vitamin $\mathrm{D}$ antar status gizi; ${ }^{* *}$ ) nilai p perbedaan ratarata kadar vitamin D antara kelompok atopi dan non atopi ; $\left.{ }^{* *}\right)$ nilai p interaksi antara atopi dan status gizi terhadap kadar vitamin D 
dan obesitas. Rerata kadar vitamin D berada dalam kadar insufisiensi vitamin $\mathrm{D}(15-29 \mathrm{ng} / \mathrm{mL})$, baik pada kelompok obesitas maupun gizi normal. Tidak terdapat perbedaan suplementasi vitamin $\mathrm{D}$ dan asupan susu (termasuk sereal, coklat) dalam 30 hari terakhir yang dapat menjadi variabel perancu sehingga tidak diikutsertakan dalam menguji hubungan kadar vitamin $\mathrm{D}$ dengan anak atopi dan obesitas.

Kadar vitamin D rendah yang berada dalam kadar insufisiensi, baik kelompok obesitas maupun gizi normal, penyebabnya belum dapat diketahui secara pasti. Penelitian terdahulu yang dilakukan oleh Turer dkk, ${ }^{11}$ terhadap anak berusia 6-18 tahun menggunakan studi cross sectional dengan data berasal dari NHANES 2003-2006, menyatakan bahwa prevalensi tinggi kadar vitamin $\mathrm{D}$ yang rendah adalah pada kelompok anak obesitas dan overweight. Pada penelitian lain, Olson $\mathrm{dkk}^{2}$ menggunakan studi cross sectional dengan matching kelompok berdasarkan usia, musim, dan etnis. Analisis data dilakukan dengan regresi logistik dan two-way Anova terhadap anak berusia 6-16 tahun juga memperlihatkan bahwa defisiensi vitamin D lebih banyak terjadi pada anak dengan obesitas. Faktor melewatkan makanan pagi dan asupan minuman bersoda menjadi dua prediktor dalam penurunan kadar vitamin D. Paparan tubuh dengan sinar matahari yang lebih rendah dari anjuran, ${ }^{12-14}$ pigmen kulit (melanin) dapat menurunkan absorpsi sinar radiasi UVB (ultraviolet B) karena terhalang oleh melanin sehingga kadar vitamin D menjadi rendah, ${ }^{13}$ sedentary life style, kegiatan lebih banyak dihabiskan di dalam ruangan, diet kurang mengandung vitamin $\mathrm{D}$, kurangnya pemberian suplementasi vitamin $\mathrm{D}^{15}$ maupun pemberian makanan yang telah difortifikasi vitamin D seperti yang telah dilakukan di Amerika Serikat dapat menjadi penyebab kadar vitamin D yang rendah.

Penelitian kami menggunakan skin prick test dalam menentukan kondisi atopi terhadap subjek penelitian. Terbukti tidak mendapatkan hubungan kadar vitamin D dengan atopi pada anak obesitas, terlihat dari kadar vitamin D anak atopi yang terendah $(4,78 \mathrm{ng} /$ $\mathrm{mL})$ hingga tertinggi $(30,65 \mathrm{ng} / \mathrm{mL})$. Demikian pula, rentang yang tidak jauh berbeda diperlihatkan oleh anak yang non atopi, terendah $(5,89 \mathrm{ng} / \mathrm{mL})$ hingga tertinggi $(40,51 \mathrm{ng} / \mathrm{mL})$.

Di Amerika Serikat, penelitian NHANES ${ }^{16}$ 2005-2006 menggunakan metode regresi logistik dan linear untuk meneliti hubungan antara defisiensi vitamin D dengan sensisitisasi alergi. Hasil penelitian tersebut menunjukkan bahwa defisiensi vitamin D berhubungan dengan kadar sensitisasi IgE yang tinggi pada anak dan remaja, tetapi tidak konsisten pada orang dewasa dengan menilai pula secara spesifik berdasarkan masing-masing allergen. Pemeriksaan menggunakan IgE serum spesifik dan skin prick test tidak memiliki relevansi biologis dan klinis yang sama sehingga tidak dapat saling menggantikan satu sama lainnya. ${ }^{17}$

Di Boston, penelitian serupa pada pasien berusia $\geq 10$ tahun dengan penilaian status gizi berdasarkan BMI yang telah tercatat di the weight center dan dilakukan pemeriksaan vitamin $\mathrm{D}$ secara rutin pada kunjungan awal masuk rumah sakit, mendapatkan hasil adanya hubungan antara status vitamin D dengan dermatitis atopik. ${ }^{10}$ Terdapat perbedaan antara penelitian ini dengan penelitian sebelumnya. Penelitian ini tidak membagi secara spesifik berdasarkan masingmasing penyakit atopik, seperti yang dilakukan banyak penelitian sebelumnya. Di samping itu, penelitian ini memiliki kelebihan dibandingkan penelitian di Boston, menggunakan skin prick test untuk menyatakan pasien atopi positif/negatif serta menggunakan kuosioner ISAAC untuk melihat manifestasi penyakit atopik, sedangkan penelitian di Boston hanya menggunakan anamnesis untuk mengetahui adanya penyakit atopik.

Hingga saat ini, penelitian yang menilai hubungan antara kadar vitamin D dengan kondisi atopi masih kontradiktif. Penelitian yang menyatakan bahwa semakin tinggi kadar vitamin $\mathrm{D}$ akan lebih berisiko untuk terjadinya manifestasi penyakit atopik lebih banyak membahas mengenai pemberian suplementasi vitamin D sebelumnya pada ibu hamil atau pemberian suplementasi pada anak di usia tahun pertama kehidupan. ${ }^{8,9} \mathrm{Di}$ Swedia dilakukan penelitian terhadap 206 bayi yang diberikan suplementasi vitamin $\mathrm{D}_{3}$ pada usia 6 minggu-24 bulan, ternyata secara signifikan akan mengalami manifestasi atopi pada usia 6 tahun. ${ }^{8}$ Penelitian pada hewan tikus yang menyatakan bahwa hormon vitamin $\mathrm{D}$ aktif, D 1,25- $(\mathrm{OH})_{2}$ akan meningkatkan interleukin (IL)-4 dan IL-13 yang menstimulasi produksi Immunoglobulin $\mathrm{E}$ (IgE) pada tikus yang merupakan respon terhadap Th-2 yang pro alergi. ${ }^{18}$ Penelitian di United Kingdom diperlihatkan ibu-ibu hamil yang memiliki konsentrasi vitamin D $25-\mathrm{OH}>75 \mathrm{nmol} / 1$ berisiko tinggi untuk memiliki anak yang mengalami dermatitis atopik pada usia 9 bulan dan asma pada 
usia 9 tahun. ${ }^{9}$ Hal tersebut memperlihatkan bahwa kaitan antara kadar vitamin D dengan terjadinya atopi dan manifestasi penyakit atopik masih memerlukan penelitian lebih lanjut.

Keterbatasan dalam penelitian ini adalah studi atopi tidak menilai secara spesifik berdasarkan tipe alergen yang diteliti. Penelitian lebih lanjut perlu menilai aktivitas fisik serta dietary recall yang lebih mendalam dari anamnesis (kuosioner). Sebaliknya, kelebihan penelitian ini adalah penelitian mengenai vitamin D dan atopi yang pertama kali dilakukan di Indonesia dan Asia, serta menggunakan skin prick test dalam melakukan uji alergi.

Penelitian kami memperlihatkan tidak terdapat hubungan kadar vitamin D dengan anak atopik dan obesitas. Perlu dilakukan penelitian lebih lanjut yang meneliti hubungan kadar vitamin $\mathrm{D}$ dengan kondisi atopi secara spesifik berdasarkan jenis alergen, serta hubungan kadar vitamin D dengan manifestasi penyakit atopik secara spesifik berdasarkan jenis penyakit dengan jumlah subjek yang lebih besar.

\section{Daftar pustaka}

1. Vimaleswaran K, Berry D, Lu C, Tikkanen E, Pilz S, Hiraki L, dkk. Causal relationship between obesity and vitamin $\mathrm{D}$ bi-directional mendelian randomization anaysis of multiple cohort. PLOS Med 2012;10:1-13.

2. Olson M, Maalouf N, Oden J, White P, Hutchison M. Vitamin D deficiency in Obese children and its relationship to glucose hemeostasis. J Clin Endocrinol Metab 2012;97:279-85.

3. Sartika R. Faktor risiko obesitas pada anak 5-15 tahun di Indonesia. Makara Kesehatan 2011;15:37-43.

4. Adams J, Hewison M. Update in vitamin D. J Clin Endocrinol Metab 2010;95:471-8.

5. Li J, Byrne M, Chang E, Jiang Y, Donkin S, Buhman $\mathrm{K}$, dkk. 1alfa-dihydroxyvitamin $\mathrm{D}$ hydroxylase in adipocytes. J Steroid Biochem Mol Biol 2008;112:1226.

6. Tsuji K, Maeda T, Kawane T, Matsunuma A, Horiuchi N. Leptin stimulates fibroblast growth factor 23 expression in bone and suppresses renal 1alfa,25-dihydroxyvitamin D3 synthesis in leptin-deficient Mice. J Bone and Min Res 2010;25:1711-23.

7. Benson A, Toh J, Vernon N, Jariwala S. The role of vitamin $\mathrm{D}$ in the immunopathogenesis of allergic skin diseases. Allergy 2011:1-6.

8. Back O, Blomquist H, Hernell O, Stenberg B. Does vitamin D intake during infancy promote the development of atopic allergy? Acta Derm Venereol 2009;89:28-32.

9. Gale C, Robinson S, Harvey N, Javaid M, Jiang B, Martyn C, dkk. Maternal vitamin D status during pregnancy and child outcomes. Euro J Clin Nutr 2008;62:68-77.

10. Oren E, Banerji A, Camargo CJ. Vitamin D and atopic disorders in an obese population screened for vitamin D deficiency. J Allergy Clin Immunol 2008;121:533-4.

11. Turer C, Lin H, Flores G. Prevalence of Vitamin D deficiency among overweight and obese US children. AAP 2013;e132:152-61.

12. Balasaraswathy $P$, Kumar U, Srinivas C, Nair S. UVA and UVB in sunlight, optimal utilization of UV rays in sunlight for phototherapy. IJDVL 2002;68:198-201.

13. Holick M. Vitamin D deficiency. N Engl J Med 2007;357:266-81.

14. Zhang R, Naughton D. Vitamin D in health and disease: current perspective. Nutr J 2010;9:65.

15. J W, LY M, TC C, Z L, MF H. Decreased bioavailibility of vitamin D in obesity. Am J Clin Nutr 2000;72:6903.

16. Sharief S, Jariwala S, Kumar J, Muntner P, Melamed M. Vitamin D levels and food and enviromental allergies in the United States: results from the national health and nutritional examination survey 2005-2006. Am Academy Allergy, Asthma \& Immunology 2011;127:1 195-202.

17. Bousquet J, Heinzerling L, Bachert C, Papadopoulos N, Bousquet P, Burney P, dkk. Practical guide to skin prick test in allergy to aeroallergens. Allergy 2011;67:18-24.

18. Matheu V, Back O, mondoc E, Issazadeh S. Dual effect of vitamin D-induced alteration of Th1/Th2 cytokine expression: enhancing IgE production and decreasing airway eosinophilia in murine allergic airway disease. J Allergy Clin Immunol 2003;112:585-92. 